\title{
Transport and Localization of the DEG/ENaC Ion Channel BNaC1 $\alpha$ to Peripheral Mechanosensory Terminals of Dorsal Root Ganglia Neurons
}

\author{
Jaime García-Añoveros, ${ }^{1}$ Tarek A. Samad, ${ }^{2}$ Ljiljana Žuvela-Jelaska, ${ }^{1}$ Clifford J. Woolf,, ${ }^{2}$ and David P. Corey ${ }^{1}$ \\ ${ }^{1}$ Howard Hughes Medical Institute and Department of Neurobiology, Massachusetts General Hospital and Harvard \\ Medical School, Boston, Massachusetts 02114, and 2Neural Plasticity Research Group, Department of Anesthesia and \\ Critical Care, Massachusetts General Hospital and Harvard Medical School, Charlestown, Massachusetts 02129
}

\begin{abstract}
Mammalian brain sodium channel (BNaC, also known as BNC/ ASIC) proteins form acid-sensitive and amiloride-blockable sodium channels that are related to putative mechanosensory channels. Certain BNaC isoforms are expressed exclusively in dorsal root ganglia (DRG) and have been proposed to form the ion channels mediating tissue acidosis-induced pain. With antibody labeling, we find that the $\mathrm{BNaC} 1 \alpha$ isoform is expressed by most large DRG neurons (low-threshold mechanosensors not involved in acid-induced nociception) and few small nociceptor neurons (which include high-threshold mechanoreceptors). $\mathrm{BNaC} 1 \alpha$ is transported from DRG cell bodies to sensory
\end{abstract}

terminals in the periphery, but not to the spinal cord, and is located specifically at specialized cutaneous mechanosensory terminals, including Meissner, Merkel, penicillate, reticular, lanceolate, and hair follicle palisades as well as some intraepidermal and free myelinated nerve endings. Accordingly, $\mathrm{BNaC} 1 \alpha$ channels might participate in the transduction of touch and painful mechanical stimuli.

Key words: DEG/ENaC channels; mechanosensory; mechanotransduction; touch; nociception; dorsal root ganglion; unidirectional transport; degenerin
Ion channel subunits of the degenerin/epithelial sodium channel (DEG/ENaC) family have two transmembrane domains and a large extracellular loop. They form homomeric or heteromeric channels that are blocked by amiloride and that are permeable to sodium and sometimes other monovalent cations, but rarely calcium. These channels are not gated by voltage but by diverse stimuli, including extracellular protons, neuropeptides, and perhaps mechanical forces (see Fig. 1; Corey and García-Añoveros, 1996; Duggan et al., 2000).

One branch of the DEG/ENaC family, the degenerins, form ion channels (García-Añoveros et al., 1998) that are needed for mechanosensation in nematodes. MEC-4 and MEC-10 are required for touch perception by six touch receptor neurons (Driscoll and Chalfie, 1991; Huang and Chalfie, 1994), UNC-8 has been implicated in proprioception (Tavernarakis et al., 1997), and UNC-105 has been implicated in response to muscle stretch (Liu et al., 1996). It has been proposed that degenerin channels are tethered both to the extracellular matrix and the cytoskeleton and that the tension between these gates the channel (GarcíaAñoveros et al., 1995; García-Añoveros and Corey, 1996, 1997).

The pickpocket (PPK) protein in insects represents another branch. It is localized at the peripheral dendrites of a subset of suspected mechanosensory neurons that innervate the insect skin

Received Sept. 27, 2000; revised Jan. 24, 2001; accepted Jan. 26, 2001.

This work was supported by the Howard Hughes Medical Institute (D.P.C.) and by National Institutes of Health Grant NS38253-01 (C.J.W.). D.P.C. is an Investigator and J.G.-A. is an Associate of the Howard Hughes Medical Institute. We are indebted to Dr. Anne Duggan for materials and experimental advice and to Dr. Frank Rice for expert anatomical advice. We thank Alo Basu for antibody purification.

Correspondence should be addressed to Dr. Jaime García-Añoveros at the above address. E-mail: anoveros@helix.mgh.harvard.edu.

Copyright (C) 2001 Society for Neuroscience $0270-6474 / 01 / 212678-09 \$ 15.00 / 0$ and has been proposed to function as a mechanosensitive channel (Adams et al., 1998; Darboux et al., 1998).

The mammalian epithelial sodium channels $(\mathrm{ENaCs})$ are a third branch. They are expressed in epithelia lining the lumen of the kidney, colon, and lung and form channels that constitutively reabsorb sodium and are not gated directly by any known stimuli (Canessa et al., 1993, 1994). However, some of these also are expressed at the baroreceptor terminals of nodose ganglion neurons, where they are proposed to form mechanically gated channels involved in the sensing of blood pressure (Drummond et al., 1998).

We and others have cloned mammalian channels that constitute a fourth branch of the $\mathrm{DEG} / \mathrm{ENaC}$ family: the brain sodium channel subunits (BNaCs, also known as BNCs or ASICs; Price et al., 1996; Waldmann et al., 1996, 1997; García-Añoveros et al., 1997; Ishibashi and Marumo, 1998; Babinski et al., 1999). BNaC channels are activated by extracellular protons (see Fig. $2 A$; Waldmann and Lazdunski, 1998), and the proton-induced currents of many are enhanced by FMRFamide neuropeptides (Askwith et al., 2000). The $\mathrm{BNaC}$ branch contains five known genes, some of which are alternative-spliced (Fig. 1B). Certain splice forms of $\mathrm{BNaC} 1$ and $\mathrm{BNaC} 2$ are widely expressed in brain neurons (García-Añoveros et al., 1997; Waldmann and Lazdunski, 1998). However, ASIC $\beta\left(\mathrm{BNaC}_{2} \beta\right)$ and DRASIC isoforms are expressed nearly exclusively in subsets of cells of the dorsal root ganglia (Chen et al., 1998; Waldmann and Lazdunski, 1998). Because tissue acidosis is a source of inflammatory pain and a sensitizing agent for other painful stimuli such as heat (Bevan and Geppetti, 1994; Reeh and Steen, 1996), it has been proposed that some $\mathrm{BNaC} / \mathrm{ASIC}$ channels are involved directly in acid-induced or acid-modulated pain (Waldmann and Lazdunski, 1998). However, others have attributed the sustained acid-induced currents characteristic of nociceptors to the capsaicin receptor, termed 


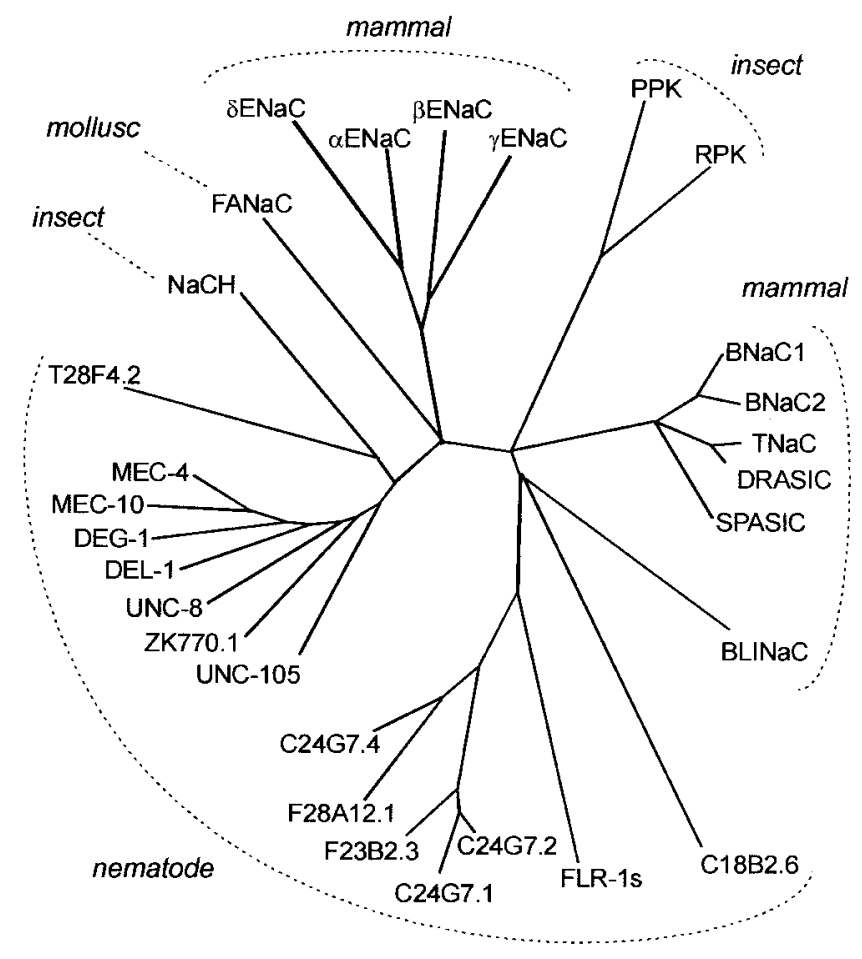

gene

protein isoforms

\section{ACCN1

\begin{abstract}
$\mathrm{BNaC} 1 \alpha / \mathrm{BNC} 1 /$ MDEG1/ ASIC2a
\end{abstract}

ACCN2

$\mathrm{BNaC} 2 \alpha / \mathrm{ASIC} 1$

\section{$\mathrm{BNaC1 \beta /MDEG2/}$ $\mathrm{ASIC} 2 \mathrm{~b}$}

$\mathrm{BNaC} 2 \beta / \mathrm{ASIC} 1 \beta$

\section{ACCN3 TNaC/ ASIC3/ DRASIC}

\section{-- SPASICI ASIC4}

Figure 1. Top, Phylogenetic tree of the DEG/ENaC ion channel family, which contains proteins from nematodes, insects, mollusks, and mammals. Bottom, Members of the $\mathrm{BNaC}$ branch, with assigned human gene names and the protein isoforms resulting from alternative splicing. The various names of each isoform are separated by slashes.

vanilloid receptor 1 (VR1; Caterina et al., 1997, 2000; Tominaga et al., 1998).

Now we have cloned $\mathrm{BNaC} 1 \alpha$ from mouse. Although earlier studies that used in situ hybridization failed to find this isoform in the DRG (Waldmann and Lazdunski, 1998), we find that it is expressed in that subset of DRG neurons likely to be mechanosensors, transported exclusively to the periphery, and localized at specialized mechanosensory terminal endings. This distribution is compatible with a possible role for $\mathrm{BNaC} 1 \alpha$ in cutaneous mechanosensory transduction.

\section{MATERIALS AND METHODS}

Cloning. On the basis of our partial cDNA clone of mouse BNaC1 (García-Añoveros et al., 1997), we designed oligonucleotides MB1-A3 (GGTCTCACAGTCGATCCGACAGGCTG) and MB1-S4 (TACAGCATCACAGCCTGTCGGATCGAC) and performed 5' and $3^{\prime}$ rapid amplification of cDNA ends (RACE) from Marathon-ready mouse brain cDNA (Clontech, Palo Alto, CA). Then the two overlapping cDNA fragments that were obtained were sequenced.

Mapping. We found a polymorphism in the $3^{\prime}$-untranslated region (UTR) sequence of $\mathrm{BNaC1}$, between the Spretus and C57BL/6J mouse strains, which could be detected by PCR amplification with primers MB1-S11 (TCAGGCAGCCCAGCACCTCCAAACAG) and MB1-A10
(GTCACAGGGAGAGAACAAAGTGGCTCC), followed by restriction digestion with $S m a \mathrm{I}$. We typed the Jackson Laboratories (Bar Harbor, ME) backcross B6xSpret mapping panels (BSB Panel 1 and BBS Panel2, each with DNA from 94 backcross progeny) for this polymorphism to determine the map position of $\mathrm{BNaC1}$.

$R T-P C R$ and in situ hybridization. Total RNA was isolated from rat lumbar DRGs (L4-L6) with Trizol (Life Technologies, Gaithersburg, $\mathrm{MD}$ ), and first-strand cDNA was synthesized with either oligo-dT or random hexamer primers, using the Gibco Superscript Preamplification System (Life Technologies). One-tenth of the resulting cDNAs (or water as negative control) was used as a template for PCR amplification with the $\mathrm{BNaC} 1 \alpha$-specific primers rmB1a-S1 (ATGGACCTCAAGGAGAGCCCCAG) and rmB1a-A1 (AAGTCTTGATGCCCACACTCCTGC). The resulting $548 \mathrm{bp}$ fragment (corresponding to $\mathrm{BNaC1} \alpha$ codons 1-183) was subcloned into the pCRII vector (Invitrogen, San Diego, CA), confirmed by DNA sequencing, linearized, and used as a template for in vitro transcription in the presence of digoxigenin-labeled cRNA probes (Promega, Madison, WI). Antisense probe was obtained by linearization with XhoI and transcription with SP6 RNA polymerase. Sense probe was obtained by linearization with $K p n I$ and transcription with T7 RNA polymerase. These probes were used to hybridize sections of rat DRG as described (Amaya et al., 2000).

Antibody generation and purification. Peptide MDLKESPSEGSLQPSSC (corresponding to residues 1-16 of mouse, rat, and human $\mathrm{BNaC} 1 \alpha$, plus a cysteine for conjugation) was synthesized by Chiron Technologies (San Diego, CA). Peptide (5 mg each) was conjugated to keyhole limpet hemocyanin (KLH). Rabbit R6798 was immunized with injections of the KLH-conjugated peptides, and anti-BNaC1 $\alpha$ antibodies were affinity-purified by passing the purified IgGs through SulfoLink columns (Pierce, Rockford, IL) to which the unconjugated $\mathrm{BNaC} 1 \alpha$ peptide had been immobilized.

We purchased the other antibodies that were used: mouse monoclonal anti-protein gene product (PGP) 9.5 (31A3; Biogenesis, Brentwood, NH), mouse monoclonal anti-neurofilament 200 (RT97; Biodesign International, Kennebunk, ME), mouse monoclonal anti-peripherin (mAb1527; Chemicon, Temecula, CA), and sheep anti-CGRP (Affiniti, Nottingham, UK). Secondary antibodies were purchased from Jackson ImmunoResearch (West Grove, PA).

Heterologous expression and electrophysiology. Cultured Chinese hamster ovary $(\mathrm{CHO})$ cells were cotransfected with a plasmid containing the complete coding sequence of $\mathrm{hBNaCl} \alpha$ under the cytomegalovirus $(\mathrm{CMV})$ promoter or the complete coding sequence of $\mathrm{mBNaC1} \alpha$ under the same promoter (provided by Anne Duggan, Massachusetts General Hospital) and with a marker plasmid that expresses green fluorescent protein (GFP; pEGFP-N3, from Clontech) or with pEGFP-N3 alone. To confirm that the $\mathrm{CHO}$ cells express $\mathrm{BNaC} 1 \alpha$ channels and incorporate them in the plasma membrane, we recorded acid-induced currents with whole-cell patch clamp (Fig. $2 A$ ). We used $\mathrm{CHO}$ cells because human embryonic kidney (HEK) 293 cells have an endogenous acid-activated amiloride-sensitive channel very similar to that produced by $\mathrm{BNaC}$ channels, and COS cells often display a slowly developing, amilorideinsensitive acid-activated current (our unpublished observations). The pipette solution contained (in mM): $140 \mathrm{CsCl}$, 5 EGTA, and 10 HEPES, $\mathrm{pH}$ 7.4. To activate $\mathrm{BNaC} 1 \alpha$ or $\mathrm{BNaC} 2 \alpha$ channels, we replaced the extracellular solution [containing (in $\mathrm{mM}$ ): $140 \mathrm{NaCl}, 5 \mathrm{KCl}, 2 \mathrm{CaCl}_{2}, 2$ $\mathrm{MgCl}_{2}, 10$ glucose, and 10 HEPES, pH7.4] with a similar solution buffered to $\mathrm{pH} 5.0$ with MES. Partial block was obtained with $500 \mu \mathrm{M}$ amiloride in the bath solution. Then the antiserum raised against $\mathrm{BNaC1} \alpha$ (R6798) was tested on CHO cells expressing hBNaC1 $\alpha$ or $\mathrm{mBNaC} 1 \alpha$ by immunocytochemistry (Fig. $2 B, C$ ) and Western blots (Fig. 2E).

Animals and tissues. We used adult CD1 mice and male Sprague Dawley rats (200-250 gm) from Charles River Farms (Wilmington, MA). To obtain total protein or RNA, we dissected rat lumbar dorsal root ganglia (L4, L5, and L6). For immunohistochemistry, rat and mouse tissues (paws or paw skin, whisker pads, DRGs, and sciatic and dorsal root nerves) were dissected, usually after cardiac perfusion of terminally anesthetized animals with $4 \%$ paraformaldehyde (PFA) in PBS. Tissues were post-fixed in $4 \% \mathrm{PFA}$ in PBS at $4^{\circ} \mathrm{C}$ for $2 \mathrm{hr}$ and decalcified in 100 mM EDTA in PBS at $4^{\circ} \mathrm{C}$ if they contained bone. Frozen sections of $10-20 \mu \mathrm{m}$ were collected on gelatin-covered slides.

Animals were operated on under halothane anesthesia (2\%). Sciatic nerves were tied with a single $5 / 0$ silk ligature at the level of the mid-thigh. L4 and L5 dorsal roots were tied similarly after a hemilaminectomy of the L2 and L3 vertebrae. At $3 \mathrm{~d}$ after the ligations, the nerves 

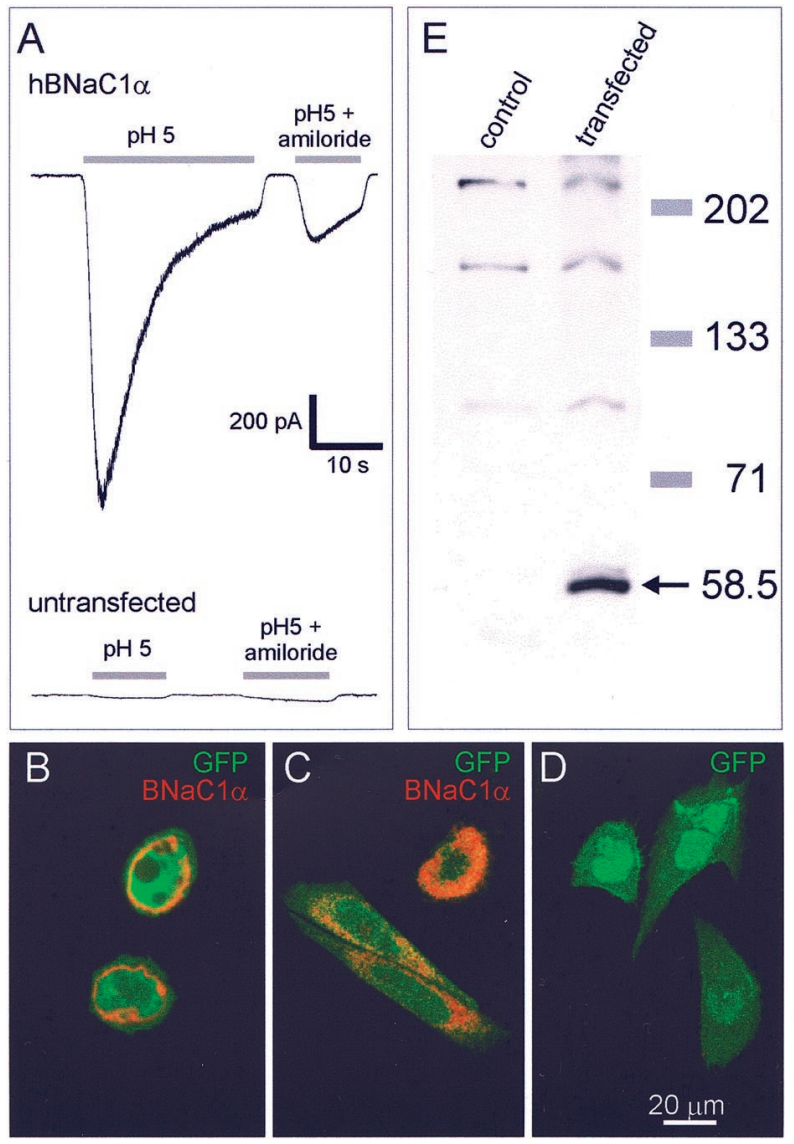

Figure 2. Antibody recognition of $\mathrm{BNaC} 1 \alpha$ heterologously expressed in cultured $\mathrm{CHO}$ cells. $A$, Currents elicited by extracellular acidic $\mathrm{pH}$ in cultured $\mathrm{CHO}$ cells expressing $\mathrm{BNaC} 1 \alpha$. Currents were blocked by 500 $\mu \mathrm{M}$ amiloride and were absent from control $\mathrm{CHO}$ cells. $B-D$, Immunocytochemical labeling with the anti-BNaC1 $\alpha$ antibody R6798 (red) of cells expressing human $\mathrm{BNaC} 1 \alpha(B)$ or mouse $\mathrm{BNaCl} \alpha(C)$ and showing the absence of labeling in control cells $(D)$. Cells in all three conditions express GFP as a marker. $E$, Western blot detection of a $58.5 \mathrm{kDa}$ protein from extracts of $\mathrm{hBNaCl} 1 \alpha$-expressing cells, but not of control cells.

were dissected, mounted in O.C.T., frozen, and processed for cryosectioning and immunohistochemistry. The animal protocols were approved by the Animal Use Committee of Massachusetts General Hospital.

Immunoblots. Total protein was purified from $\mathrm{CHO}$ cells transfected as indicated above or from dissected rat DRGs. Scraped cells or diced tissues were homogenized in the presence of ice-cold RIPA lysis buffer (1\% Nonidet P-40, $0.5 \%$ sodium deoxycholate, and $0.1 \%$ SDS, in PBS) containing protease inhibitors $(2 \mu \mathrm{g} / \mathrm{ml}$ leupeptin and $2 \mu \mathrm{g} / \mathrm{ml}$ pepstatin). After the addition of PMSF to $0.1 \mathrm{gm} / \mathrm{ml}$ and incubation for $30 \mathrm{~min}$ on ice, the samples were centrifuged at $10,000 \times g$ for $20 \mathrm{~min}$ at $4^{\circ} \mathrm{C}$, and the lysis was collected from the supernatant. Lysate containing 10-20 $\mu \mathrm{g}$ of total protein was run by SDS-PAGE (Bio-Rad, Hercules, CA) and transferred to Hybond ECL nitrocellulose membranes (Amersham Pharmacia Biotech, Buckinghamshire, UK). The filters were probed with the anti-BNaC1 $\alpha$ antibody R6798, using the ECL Western blotting analysis system (Amersham Pharmacia Biotech).

Immunocytochemistry. CHO cells were fixed in 4\% PFA in PBS for 10 min, rinsed five times with PBS for 10 min each, permeabilized with $0.1 \%$ Triton X-100 for $15 \mathrm{~min}$, rinsed five times with PBS for $10 \mathrm{~min}$ each, blocked with $1 \%$ normal goat serum and 5\% BSA in PBS for $1-2 \mathrm{hr}$, and incubated with anti-BNaC1 $\alpha$ antibodies diluted in $0.5 \%$ normal goat serum and $0.5 \%$ BSA in PBS at $4^{\circ} \mathrm{C}$ overnight. After five washes in $0.5 \%$ BSA in PBS, the cells were incubated in Cy-3 goat anti-rabbit (1:100; Jackson ImmunoResearch) in $0.5 \%$ normal goat serum and $0.5 \%$ BSA in PBS for $1 \mathrm{hr}$, washed three times in $0.5 \%$ BSA in PBS for 5 min each and two times in PBS, covered with anti-fade reagent (Gelmount, Bio-Rad), and viewed with a confocal microscope (Zeiss Axiophot with a Bio-Rad Radiance 2000).
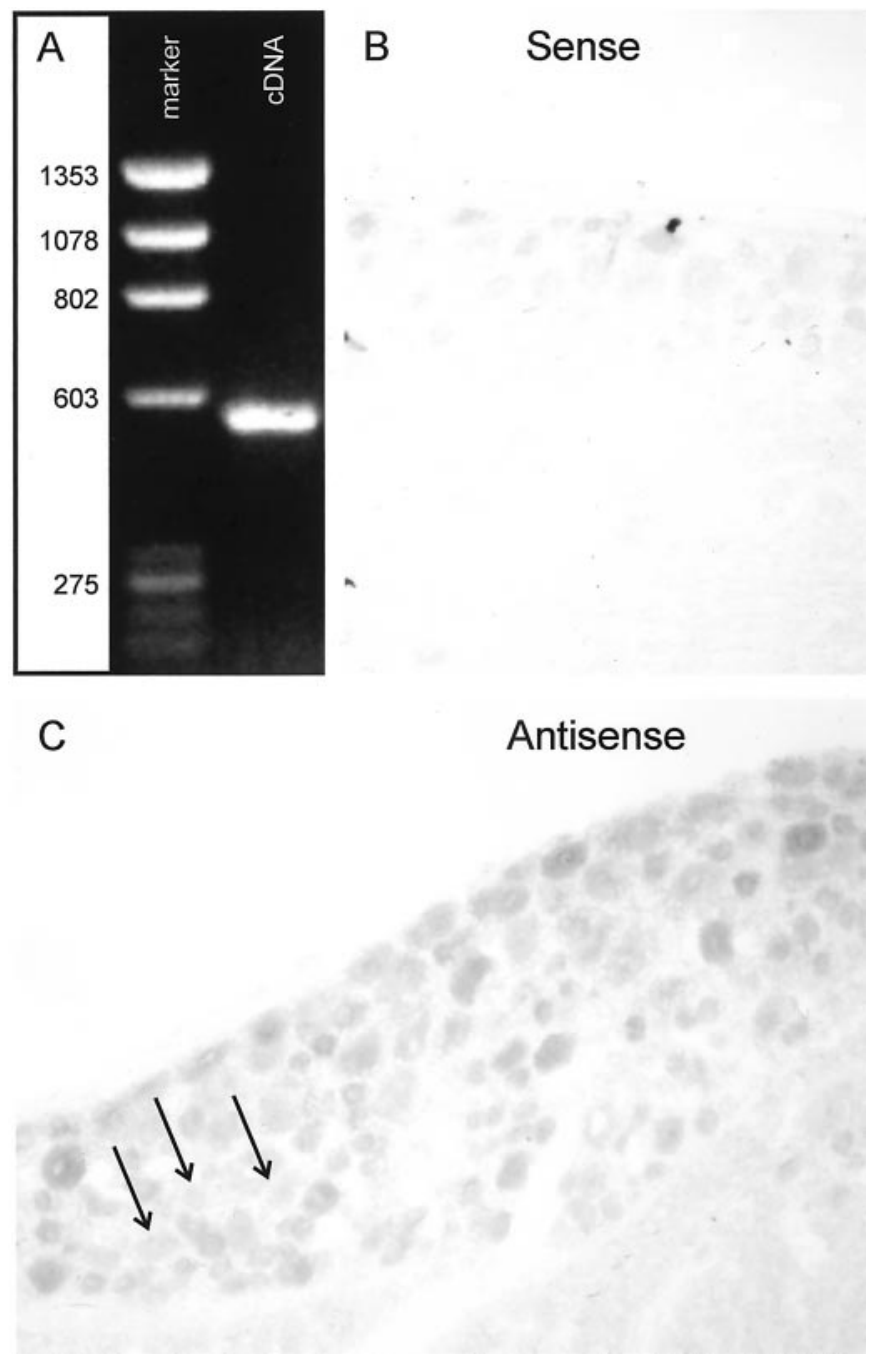

Figure 3. Expression of $\mathrm{BNaC} 1 \alpha$ mRNA in rat dorsal root ganglion. $A$, Detection of $\mathrm{mBNaC} 1 \alpha$ by RT-PCR ( 30 cycles), using DRG total RNA as a template. $B, C$, Detection by in situ hybridization with antisense digoxigenin-labeled cRNA probe $(C)$, but not with sense cRNA probe $(B)$. Arrows in $C$ point at some of the unlabeled cells.

Frozen sections were post-fixed and labeled as described above for cultured cells, but with the following alterations. Sections were blocked with either 3\% normal donkey serum and 3\% BSA in PBS or with 3\% normal goat serum and $0.3 \%$ Triton X-100 in PBS; primary antibodies were diluted in identical solutions and incubated with the sections for $2 \mathrm{~d}$ at $4^{\circ} \mathrm{C}$. Afterward, washes were performed with PBS, and secondary antibodies (FITC goat anti-rabbit and Cy-3- or Texas Red-conjugated goat anti-mouse) were diluted in the same block solution; alternatively, washes were performed with $0.05 \%$ Tween 20 in PBS, and secondary antibodies (Cy-3 donkey anti-rabbit and FITC donkey anti-mouse) were diluted in the same solution.

\section{RESULTS}

\section{Cloning and mapping of $\mathrm{mBNaC} 1 \alpha$}

On the basis of a partial mouse $\mathrm{BNaC} 1$ cDNA clone we had obtained previously, we performed RACE to generate cDNA fragments that encompass the complete coding sequence of mouse $\mathrm{BNaC} 1 \alpha$. The resulting contig consists of 225 nucleotides of 5'-UTR, 1536 nucleotides of coding sequence, and up to 891 nucleotides of $3^{\prime}$-UTR (accession number AF348465). This is the mouse ortholog of the human hBNaC1 (García-Añoveros et al., 

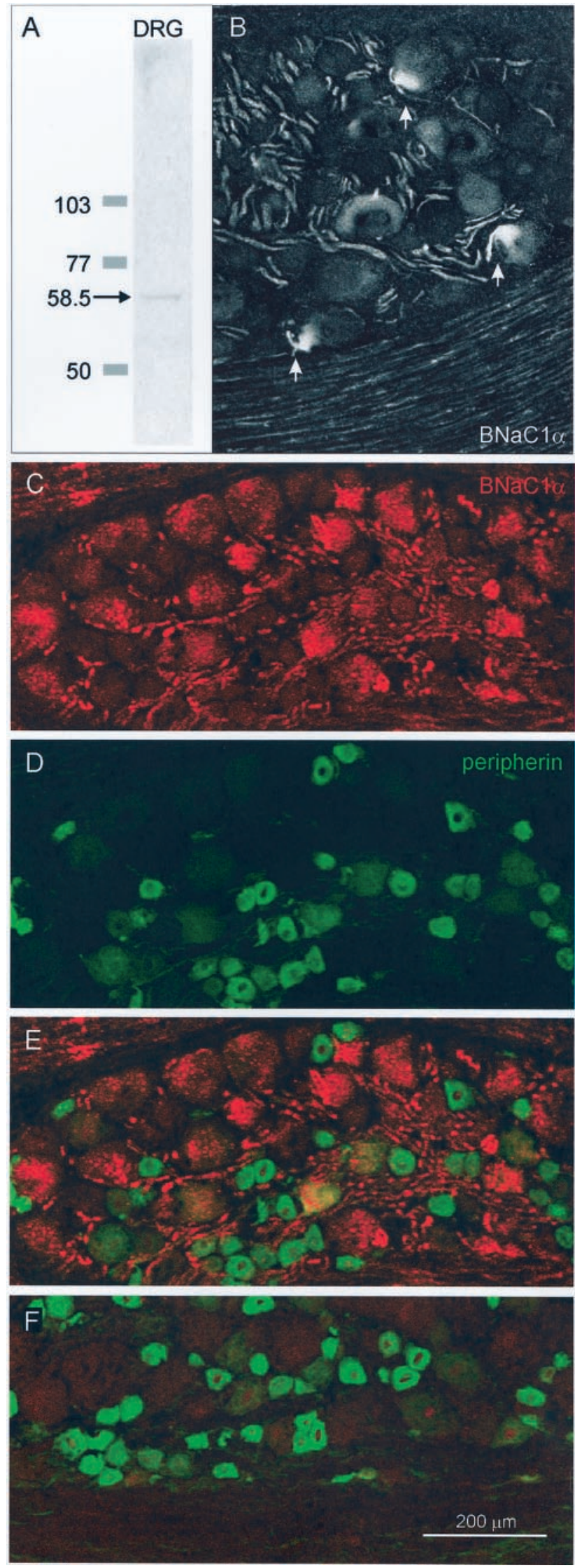

Figure 4. Expression of $\mathrm{BNaC} 1 \alpha$ protein in dorsal root ganglion. $A$, Western blot detection of $\mathrm{BNaC} 1 \alpha$ from rat lumbar $\mathrm{DRG}$ protein extract with the anti-BNaC1 $\alpha$ antibody R6798. $B$, Subcellular accumulation of
1997), also known in the rat as BNC1 (Price et al., 1996) and MDEG1 (Waldmann et al., 1996).

We mapped $\mathrm{mBNaC} 1$ to mouse chromosome 11 , linked to the mouse loci vibrator, NF1, Myo1c, and D11Mit34. This is one of the mouse genomic regions syntenic to human 17q11.2-12, where hBNaC1 maps (García-Añoveros et al., 1997). The exon encoding the $\mathrm{BNaCl} \alpha$-specific $\mathrm{N}$-terminal region is contained in mouse genomic BAC clones RP23-328G11, RP23-92G22, and RP23-433D11.

\section{Localization of BNaC1 $\alpha$ mRNA to the DRG}

$\mathrm{BNaC} 1 \alpha / \mathrm{BNC} 1 / \mathrm{MDEG} 1 / \mathrm{ASIC} 2 \mathrm{a}$ and $\mathrm{BNaC} 1 \beta / \mathrm{MDEG} 2 /$ ASIC2b are identical in their $327 \mathrm{C}$-terminal residues but differ in their $\mathrm{N}$ termini (185 residues in $\mathrm{BNaCl} \alpha$ and 236 residues in $\mathrm{BNaC} 1 \beta$ ), which include the intracellular $\mathrm{N}$ terminus, the first transmembrane domain, and 135 amino acids of the extracellular loop. With PCR primers unique to the $\mathrm{BNaC} 1 \alpha$ splice form, we performed RT-PCR with rat DRG total RNA as a template and detected $\mathrm{BNaC} 1 \alpha$ mRNA in the DRG (Fig. $3 A$ ). We then performed in situ hybridization, using a cRNA probe corresponding to the unique fragment of $\mathrm{BNaC} 1 \alpha$, and detected $\mathrm{BNaC} 1 \alpha$ mRNA in DRG, primarily in large-diameter neurons (Fig. 3B,C).

\section{Localization of $\mathrm{BNaC} 1 \alpha$ protein in the DRG}

We raised and affinity-purified an antibody (R6798) that recognizes the first 16 amino acids of mouse, rat, and human $\mathrm{BNaC} 1 \alpha$ and that differs from $\mathrm{BNaC} 1 \beta / \mathrm{MDEG} 2$. This antibody specifically labeled cultured $\mathrm{CHO}$ cells expressing human or mouse $\mathrm{BNaC} 1 \alpha$, but not untransfected cells (see Fig. $2 A-D$ ). In Western blots from transfected cells the antibody primarily recognized a protein band of $\sim 58 \mathrm{kDa}$, indistinguishable from the $57.7 \mathrm{kDa}$ predicted for $\mathrm{BNaC} 1 \alpha$ (Fig. $2 E$ ).

Similarly, on a Western blot of rat DRG proteins, the antiBNaC1 $\alpha$ antibody R6798 labeled a single band of $\sim 58 \mathrm{kDa}$ (Fig. $4 A)$. With immunofluorescence on DRG sections we found that $\mathrm{BNaC} 1 \alpha$ protein was expressed by $\sim 21 \%$ of $\mathrm{L} 4$ and $\mathrm{L} 5 \mathrm{DRG}$ neurons (Fig. 4B). Nearly all of the cells that express neurofilament 200 (a marker of the large and medium-sized, A-fiber neurons; Lawson et al., 1984; Lawson and Waddell, 1991; Sann et al., 1995) were labeled by the $\mathrm{BNaC} 1 \alpha$ antibody $(90.5 \pm 2.1 \%$, mean $\pm \mathrm{SD} ; n=528$ cells from four sections), whereas only a few of the cells that express the C-fiber marker peripherin (smalldiameter neurons; Goldstein et al., 1991) were labeled (4.1 \pm $1.6 \% \mathrm{SD} ; n=573$ cells from four sections). Within these neurons $\mathrm{BNaC} 1 \alpha$ is not concentrated in the plasma membrane but, instead, accumulates prominently in the cytoplasm adjacent to the axon hillock and in the axonal process that emerges from it (Fig. $4 C$ ). This localization suggests that $\mathrm{BNaCl} \alpha$ is transported anterogradely toward the terminals.

\section{Transport of $\mathrm{BNaC} 1 \alpha$ to the periphery}

To determine whether $\mathrm{BNaC} 1 \alpha$ is transported to peripheral sensory or central synaptic terminals, we ligated the central axons in

\section{$\leftarrow$}

$\mathrm{BNaC} 1 \alpha$ immunoreactivity (white) within the cell body near the axon hillock (arrows) and in the proximal neuronal process. $C-F$, Immunohistochemical labeling of sections of rat lumbar DRG with R6798 antibody (red; $C$ ), anti-peripherin antibody (green; D), and both $(E)$. Note the absence $\mathrm{BNaC} 1 \alpha$ from the small cells, labeled with peripherin. $F$, Peptide preincubation control. The R6798 antibody (red) was preincubated with the antigenic peptide that was used to raise it. Only nonspecific low-level background label was detected with R6798. The anti-peripherin antibody label is in green. 

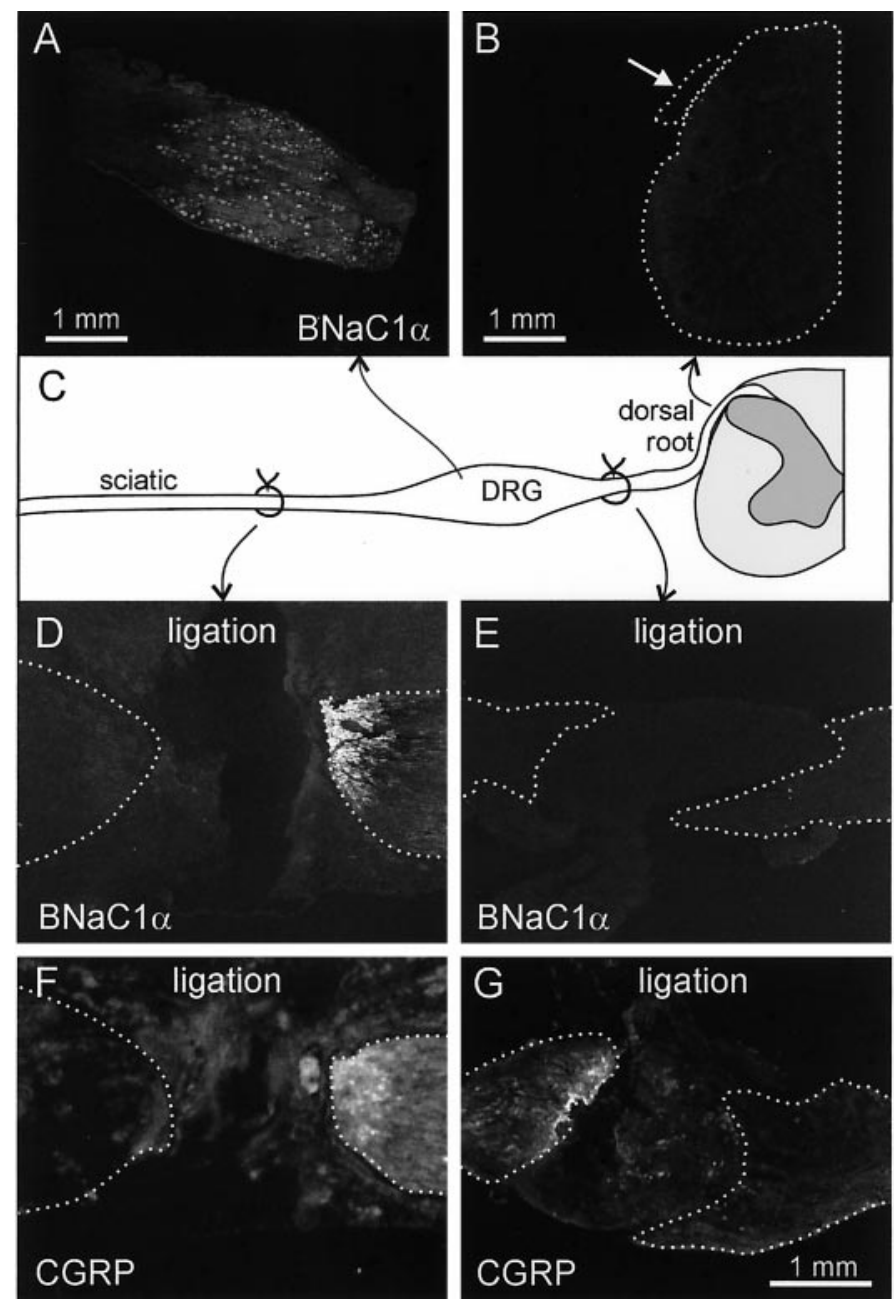

Figure 5. Unidirectional transport of $\mathrm{BNaC} 1 \alpha$ to the periphery. $A$, Section of rat lumbar dorsal root ganglion, showing abundant $\mathrm{BNaC} 1 \alpha$ immunoreactivity in the cell bodies. $B$, Section of rat lumbar dorsal root (arrow) and spinal cord (each demarcated by dotted lines), showing no detectable immunoreactivity. Sections for $A$ and $B$ were treated under the same conditions, at the same time, and were photographed with identical confocal settings. $C$, Schematic drawing of experiments in which ligatures were applied either to the peripheral sensory axons in the rat sciatic nerve $(D, F)$ or to their central axons in the L4 dorsal root $(E, G)$. D, Accumulation of $\mathrm{BNaC} 1 \alpha$ at the proximal (from $\mathrm{DRG}$ ) side of a ligated sciatic nerve. $E$, Absence of $\mathrm{BNaC} 1 \alpha$ at either side of a ligated dorsal root. The sections of both ligated dorsal roots and sciatic nerve were labeled and photographed under the same conditions. $F, G$, Control labeling demonstrating the accumulation of CGRP in adjacent sections of the same ligatures of sciatic nerve $(F)$ and dorsal $\operatorname{root}(G)$. The nerve funiculi are demarcated with a dotted white line.

the dorsal roots that extend from lumbar DRGs to the spinal cord. In a separate experiment we ligated peripheral DRG axons in the sciatic nerve that extends from lumbar DRGs to the periphery. We looked for $\mathrm{BNaC} 1 \alpha$ immunoreactivity at either side of the ligatures, because proteins that are transported orthogradely will accumulate proximal to the ligature and those retrogradely, distal. As a positive control, we found an accumulation of calcitonin gene-related peptide (CGRP) on the DRG side of both ligatures (Fig. $5 F, G$ ). By contrast, $\mathrm{BNaCl} \alpha$ immunoreactivity was not seen at either side of the ligated dorsal roots (Fig. 5E). Furthermore, we did not detect any $\mathrm{BNaC} 1 \alpha$ immunoreactivity in the unligated dorsal roots entering the lumbar spinal cord and in the dorsal columns, nor in the dorsal horn and the dorsal column nuclei, the sites of termination of cutaneous afferents (Fig. 5B; data not shown). This suggests that $\mathrm{BNaC} 1 \alpha$ is not transported toward the central, presynaptic terminals in the spinal cord. However, we detected a substantial accumulation of $\mathrm{BNaC} 1 \alpha$ on the DRG side of the ligated sciatic nerve (Fig. $5 D$ ), indicating that $\mathrm{BNaC} 1 \alpha$ is transported from DRG cell bodies toward the peripheral sensory terminals.

\section{Localization of $\mathrm{BNaC1} \alpha$ in mechanosensory terminals of the skin}

To identify the destination of $\mathrm{BNaC} 1 \alpha$ in $\mathrm{DRG}$ peripheral fibers, we labeled sections of glabrous and hairy skin with the antibody. We found that $\mathrm{BNaCl} \alpha$ immunoreactivity often colocalizes with neurofilament 200, a marker of myelinated A-fibers, which are primarily mechanosensitive (Sann et al., 1995), and is found specifically in a variety of mechanosensory terminals.

\section{Meissner corpuscles}

In the glabrous skin of rat and mouse paws, $\mathrm{BNaC} 1 \alpha$ localizes to fibers innervating Meissner corpuscles (Fig. 6A-D), structures located in the dermal papillae of the digits that are thought to be innervated by rapidly adapting mechanoreceptor fibers. These fibers extend apically on the dermal papillae and then branch and run a meandering course within the Meissner corpuscle where they terminate (Cauna and Ross, 1960; Bruce and Sinclair, 1980; Sinclair, 1982).

\section{Penicillate endings}

In the dermis of both glabrous and hairy skin, many nerve fibers contain $\mathrm{BNaC} 1 \alpha$, often extending toward the basal layer of the epidermis and then splitting into a leash of fibers that runs subepidermally under the basal layer (Fig. 6E-H). This leash of fibers has been termed the "penicillus," and its various penicillate endings attach to the basal layer of the epidermis via collagen fibers (Cauna, 1973; Sinclair, 1982), connections that might serve as points of mechanical tethering.

\section{Merkel disks}

Some of the fibers that run subepidermally end in an expanded discoid terminal in close contact with Merkel cells, specialized cells located at the base of the epidermis that are innervated by type I slowly adapting mechanoreceptor neurons (Sinclair, 1982). $\mathrm{BNaC} 1 \alpha$ was highly enriched in these Merkel disk terminals (Fig. $6 I-L)$.

\section{Intraepidermal terminals}

Other cutaneous afferent fibers do not turn as they reach the basal layer of the epidermis but, instead, penetrate into the epidermis. Most of these are unmyelinated, and most (98\% in rat glabrous skin) do not contain $\mathrm{BNaC} 1 \alpha$ (Fig. $6 Q-T, I-L$ ). This is consistent with the absence of $\mathrm{BNaC} 1 \alpha$ from $96 \%$ of the peripherin-positive cell bodies in the DRG (see Fig. $4 E$ ). However, a few intraepidermal endings originate from myelinated, A $\delta$ fibers, which express neurofilament 200 and are considered high-threshold mechanosensory (HTM) terminals that initiate the sensation of pricking pain (Kruger et al., 1981). $\mathrm{BNaCl} \alpha$ was localized at these neurofilament 200-positive intraepidermal fibers (Fig. $6 M--P)$.

\section{Hair follicle afferents}

Hair follicles are innervated by fibers that either wrap around the follicle (circumferential endings) or encircle the follicle with comb-like terminals (palisade endings); these correspond to rap- 

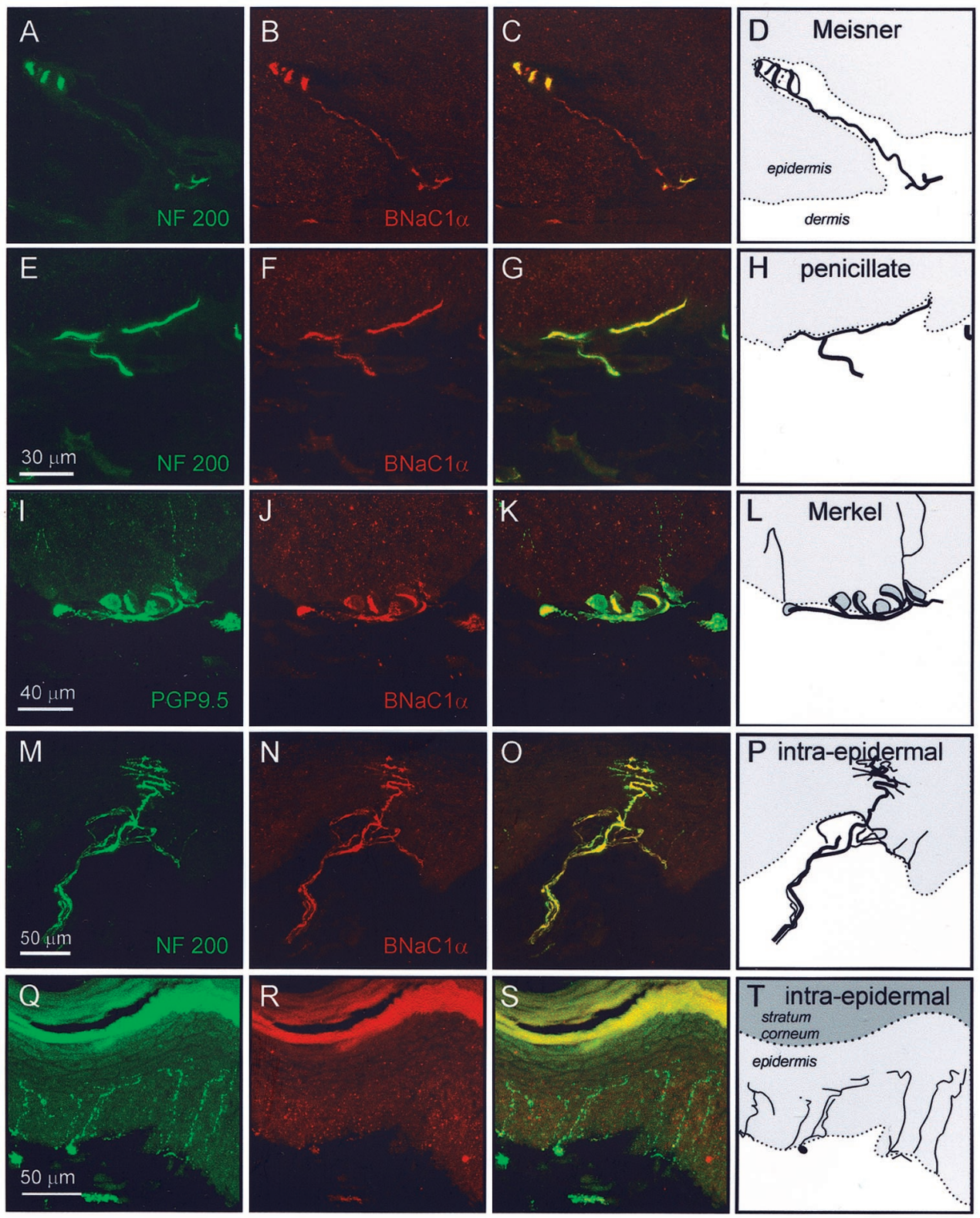

Figure 6. $\mathrm{BNaC} 1 \alpha$ localization in mechanosensory terminals of the skin. $A, E, I$, $M, Q$, Immunoreactivity to neurofilament $200(N F 200)$ or the neuronal marker PGP 9.5 (green; Thompson et al., 1983). B, F, J, $N, R$, Immunoreactivity to $\mathrm{BNaC} 1 \alpha$ (red). $C, G, K, O, S$, Merging of the images to demonstrate colocalization (yellow). $D$, $H, L, P, T$, Schematic drawing of the tissues, derived from other images of the same sections. A dotted line represents the basal membrane that separates the epidermis (gray) from the dermis (white). $A-D$, $\mathrm{BNaC} 1 \alpha$ immunoreactivity of a neurite innervating a Meissner corpuscle situated in a dermal papilla of the glabrous skin of a mouse forepaw. $E-H$, Penicillate terminals under the basal layer of the epidermis in the glabrous skin of a mouse forepaw. $I-L$, Merkel cells in the glabrous skin of the rat forepaw. The PGP 9.5 antibody (green) labels the subepidermal nerves, their terminals (the Merkel disks), and the closely apposed Merkel cells at the base of the epidermis. The $\mathrm{BNaC} 1 \alpha$ antibody (red) labels the Merkel disks and, less prominently, the neuronal processes leading to them. Note the two thin intraepidermal fibers, which do not contain $\mathrm{BNaC} 1 \alpha . M-P$, Intraepidermal fibers of myelinated origin in the glabrous skin of the rat forepaw. $Q-T$, Thin intraepidermal fibers of C-fiber origin in the glabrous skin of the rat forepaw. These fibers do not label for $\mathrm{BNaC} 1 \alpha$. The strong fluorescence signal from the stratum corneum is attributable to autofluorescence. idly adapting mechanoreceptor neurons (Sinclair, 1982; Millard and Woolf, 1988; Rice et al., 1993). BNaC1 $\alpha$ localizes to both circumferential and palisade terminals of follicles from different areas of hairy skin, such as the furry skin of the rat snout and the less hairy skin of the dorsal side of the mouse paw (Fig. 7).

\section{Vibrissal afferents}

The whiskers (or vibrissae) of the snout are the hairs with the most elaborate, varied, and complex innervation; they constitute specialized mechanosensory structures that endow most mammals with very fine tactile discrimination. The whisker follicle is formed by an epidermal layer that surrounds the base of the whisker hair and is surrounded by dermis and specialized blood sinuses (Fig. 8D). Whisker follicles are innervated by many neuronal fibers but mostly by myelinated NF200-positive neurons representing several distinct types of mechanosensory terminals. Each type of terminal not only is abundant but also innervates the follicle at a stereotyped position (Rice et al., 1993, 1997). We found that the non-mechanosensory terminals lacked $\mathrm{BNaC} 1 \alpha$ (i.e., most of the circumferential fibers; see below), whereas all types of mechanosensory terminals reaching the follicle contained $\mathrm{BNaC} 1 \alpha$. These include the reticular endings of the mesenchymal sheath that surrounds the deeper portion of the follicle (which branch profusely and terminate in contact with the basal membrane of the follicle; Fig. $8 H-J$ ), the Merkel disks situated at mid-depth along the periphery of the follicle (within its epidermis, just past the "glassy" basement membrane; Fig. $8 E-G$ ), and the lanceolate endings at approximately the same depth but in the dermis (Fig. $8 A-C$ ). More superficially, at the level of the inner conical body, many nerve fibers wrap around the follicle. Most of these are unmyelinated sensory, sympathetic, or parasympathetic fibers. However, a few of them are myelinated, express NF200, terminate as branched lanceolate endings, and are thought to be mechanosensory (Rice et al., 1997). BNaC1 $\alpha$ was present in only a few of the circumferential fibers, the ones with branched, lanceolated terminals (Fig. 8A-C).

In the reticular endings of the whisker pad (Fig. $8 H-J$ ), as well 
Figure 7. Palisade and circumferential endings around hair follicles from fur. Shown is immunoreactivity to NF200 (green), $\mathrm{BNaCl} \alpha$ (red), or both (colocalization in yellow). $A-C, E, F$, Follicles of the mouse forepaw. Note that $\mathrm{BNaCl} \alpha$ immunoreactivity is more prominent at the tips than at the base of the palisade endings (small arrows). D, Schematic drawing of a hair follicle and its innervation. $G$, Follicle of the rat mystacial fur, showing palisade endings and circumferential fibers (large arrows).

Figure 8. Innervation of rat whisker hair follicles. Shown is immunoreactivity to the neuronal marker PGP 9.5 (green), $\mathrm{BNaC1} \alpha$ (red), or both (colocalization in yellow). $A-C$, Section of whisker pad at the level of the inner conical body, with circumferential fibers (only a few of which contain $\mathrm{BNaC} 1 \alpha$; arrowheads) and vertical, lanceolate endings (bottom left). D, Schematic drawing of a whisker (vibrissal) follicle and its associated innervation, derived from Rice et al. (1993). The epidermis is in gray, and the dermis is in white; myelinated terminals are depicted as black lines and unmyelinated terminals as gray lines. $E-G$, Merkel cells and disks within the epidermis of the follicle at mid-depth. $H-J$, Section through the base of the follicle, with reticular endings that terminate in contact with the basal membrane of the follicle. The nerve that supplies all reticular, lanceolate, and Merkel endings may be observed on the left of each panel (arrows).
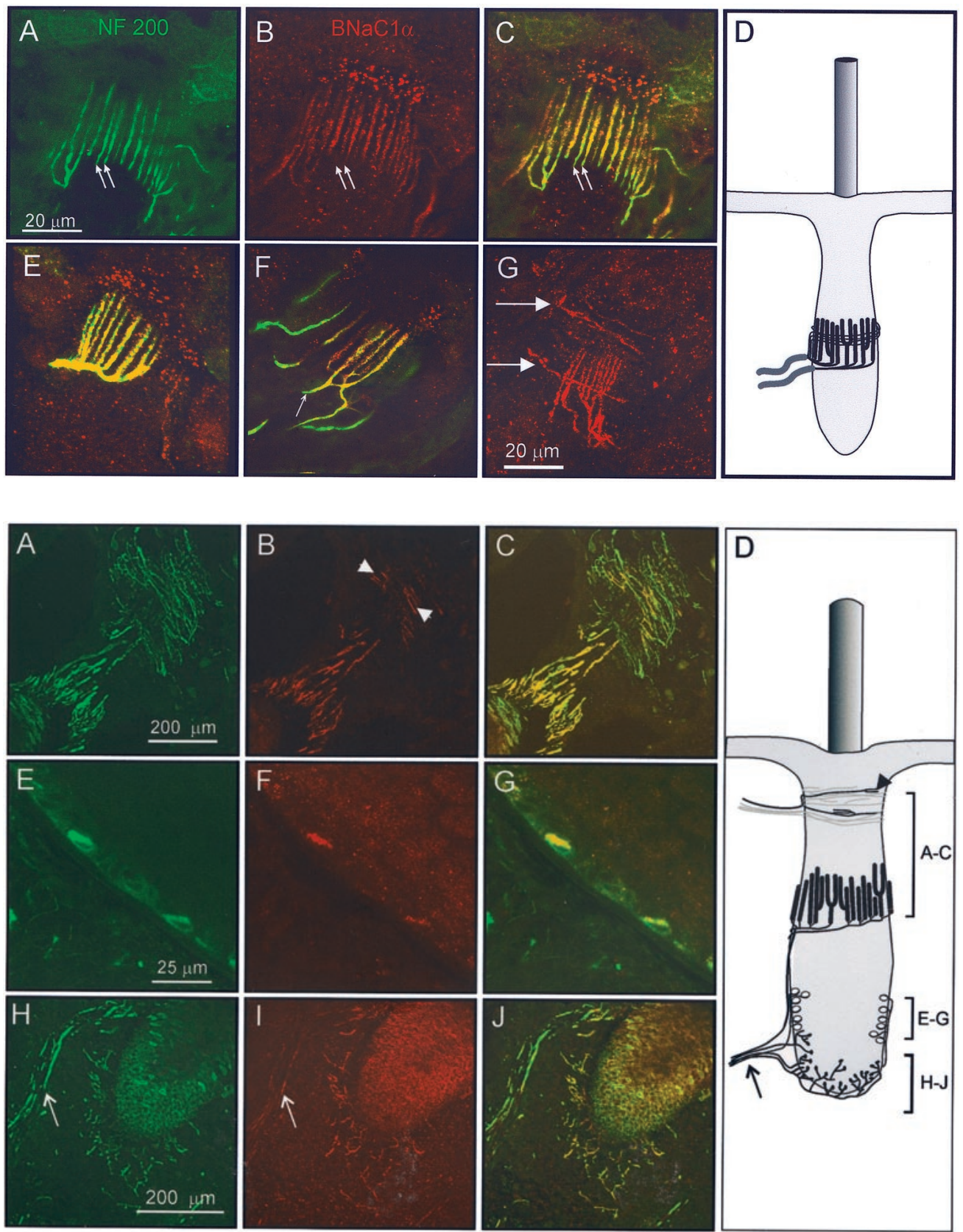

as in the palisade endings of regular hair follicles (see Fig. 7A-F), we noticed that $\mathrm{BNaC} 1 \alpha$ increases in density toward the terminals. In the fibers that contact the Merkel cells in both hairy and glabrous skin (see Figs. $6 I-L, 8 E-G$ ), $\mathrm{BNaC} 1 \alpha$ also accumulates in the terminals (the Merkel disks) and is much less abundant in the axons leading to them. Thus $\mathrm{BNaC} 1 \alpha$ is transported to and located at many, if not all, sites of mechanosensory transduction in the skin, whereas it is absent from the nerve endings that have been considered to be non-mechanosensory (Rice et al., 1997).

\section{DISCUSSION}

Although it has been reported previously that $\mathrm{BNaC} 1 \alpha$ (MDEG/ ASIC2) mRNA is not expressed in the DRG (Waldmann and Lazdunski, 1998), we found that $\mathrm{BNaC} 1 \alpha$ is expressed in the DRG, as assessed by four different methods: in situ hybridization, RT-PCR, Western blotting, and immunocytochemistry.

\section{Unidirectional protein transport within DRG neurons}

Within the cell bodies of DRG neurons, $\mathrm{BNaC} 1 \alpha$ protein has a rather distinctive subcellular localization: it is not conspicuously in the plasma membrane but accumulates in the cytoplasm near the axon hillock. Such a distribution would be expected of a protein that is actively transported from the cell body. Despite this, we found no detectable levels of $\mathrm{BNaC} 1 \alpha$ in the central synaptic terminals of DRG cells (in the spinal cord or in dorsal column nuclei) nor in the processes leading to them (the dorsal roots and the dorsal columns). However, $\mathrm{BNaC} 1 \alpha$ is clearly transported from the cell bodies toward the sensory terminals in the skin. Although we cannot rule out that very small amounts of $\mathrm{BNaC} 1 \alpha$ are present in central terminals of primary sensory neurons, it is clear that a large portion of the protein ends up localized at the peripheral terminals where sensory transduction 
occurs. The unidirectional transport of $\mathrm{BNaC} 1 \alpha$ from the cell body toward the periphery is, as far as we know, unique. Other sensory receptor channels such as the ATP-gated P2X3 (Vulchanova et al., 1998) or the capsaicin-, heat-, and pH-gated VR1 (Guo et al., 1999) are not transported exclusively to the periphery and are found in central terminals also. The peripheral transport of $\mathrm{BNaC} 1 \alpha$ indicates that there must be a selective sorting mechanism, previously unnoticed in the DRG for any protein, at the branch point of peripheral and central axons; it also suggests that this channel is involved in functions exclusive to the peripheral fibers, such as sensory transduction.

\section{The physiological function of $\mathrm{BNaC}_{1} \alpha$}

In which sensory modality might $\mathrm{BNaC} 1 \alpha$ participate? The activation of $\mathrm{BNaCl} \alpha$ (and most other $\mathrm{BNaC}$ proteins) by extracellular acidification has led to a proposal that $\mathrm{BNaC}$ channels in nociceptive DRG neurons may detect tissue acidosis and mediate acid-induced pain (Waldmann and Lazdunski, 1998). However, the sustained currents of nociceptive neurons, activated below $\mathrm{pH}$ 6.5 and lasting for minutes (Bevan and Yeats, 1991; Bevan and Geppetti, 1994), differ considerably from $\mathrm{BNaC} 1 \alpha$ currents in cultured cells, which are activated only below $\mathrm{pH} 5.5$ and inactivate within tens of seconds (see Fig. $2 A$; Waldmann and Lazdunski, 1998). More importantly, $\mathrm{BNaC} 1 \alpha$ is expressed by most large-diameter neurons, which do not exhibit the sustained acid $\mathrm{pH}$-induced current characteristic of nociceptors (Bevan and Yeats, 1991; Bevan and Geppetti, 1994). Instead, the endogenous proton-gated currents in nociceptive neurons are very similar to those of the capsaicin receptor, which is activated (with a slow inactivation) below $\mathrm{pH} 6$, and they are nearly eliminated in mutant mice with no functional VR1 (Bevan and Geppetti, 1994; Caterina et al., 1997, 2000; Tominaga et al., 1998). Therefore, $\mathrm{BNaC} 1 \alpha$ is not likely to contribute significantly to the acidsensing current characteristic of peripheral nociception, although other related isoforms of the BNaC/ASIC family may (see Benson et al., 1999).

In addition to the sustained acid-induced current of nociceptive C-fibers, most cultured DRG neurons (as well as many neurons of the CNS) are endowed with an inactivating acid-induced current (Bevan and Yeats, 1991; Bevan and Geppetti, 1994). Although these currents are activated below $\mathrm{pH} 7.0$ and heterologously expressed $\mathrm{BNaC} 1 \alpha$ channels activate only below $\mathrm{pH} 5.5$, it is conceivable that $\mathrm{BNaC} 1 \alpha$ subunits might contribute to this endogenous current (for example, as part of a heteromultimeric channel). However, the physiological role of this current is not known.

Our data show that $\mathrm{BNaC} 1 \alpha$ is expressed in that complement of DRG neurons that is expected to be mechanosensory. This includes most (90\%) of the NF200 positive large-diameter neurons, which respond to low intensity mechanical stimuli (touch, pressure, vibration, stretch, and hair displacement), as well as the NF200-positive medium-diameter and a few (4\%) of the NF200negative small-diameter neurons, some of which are highthreshold mechanonociceptors. Most suggestively, $\mathrm{BNaC} 1 \alpha$ accumulates in the skin at all of the specialized mechanosensitive endings that we have examined and not in other nonmechanosensory endings, such as the intraepidermal C-fibers or the circumferential fibers around the whisker follicle. Thus, the expression pattern of $\mathrm{BNaC} 1 \alpha$ is suggestive of a role in mechanosensitivity, whether nociceptive or innocuous.

Although the location of $\mathrm{BNaC} 1 \alpha$ in mechanosensitive terminals is not direct evidence for activation by mechanical stimuli, it is intriguing that other branches of the $\mathrm{DEG} / \mathrm{ENaC}$ channel superfamily also have been implicated in several types of mechanosensation. These include the nematode degenerins MEC-4, MEC-10, UNC-105, and UNC-8 (Driscoll and Chalfie, 1991; Huang and Chalfie, 1994; García-Añoveros et al., 1995; GarcíaAñoveros and Corey, 1996; Liu et al., 1996; Tavernarakis et al., 1997), the Drosophila PPK protein (Adams et al., 1998; Darboux et al., 1998), and mammalian ENaCs found at baroreceptor terminals (Drummond et al., 1998). We suggest, based on its distribution and localization, that $\mathrm{BNaC} 1 \alpha$ also may be a mechanosensitive channel, participating in cutaneous touch sensation in mammals.

While this paper was under review, a report was published indicating that transgenic mice with no functional $\mathrm{BNaC} 1$ have impaired mechanosensory cutaneous responses but retain normal responses to acid $\mathrm{pH}$ (Price et al., 2000). These results support the hypothesis that $\mathrm{BNaC} 1 \alpha$ mediates touch sensation.

The physiological role of the activation of $\mathrm{BNaC} 1 \alpha$ channels by protons remains unclear. It is conceivable, although rather unorthodox, that acid activation of this channel is part of the touch transduction cascade. Alternatively, it seems plausible that the effect of protons on $\mathrm{BNaC} 1 \alpha$ is modulatory and that its primary gating stimulus is force. In fact, the touch response of certain mechanosensory DRG neurons is sensitized by extracellular acidity (Steen et al., 1992).

In DRG neurons a mechanosensitive channel that can be blocked by the amiloride analog benzamil has been described, and it has been proposed that it may be a DEG/ENaC channel (McCarter et al., 1999). On the other hand, with heterologous expression of either $\mathrm{BNaC} 1 \alpha$ or the nematode degenerin UNC105 in $\mathrm{CHO}$ cells, we cannot elicit mechanosensitive currents (data not shown). Other attempts to activate mechanically the $\mathrm{DEG} / \mathrm{ENaC}$ channels expressed in heterologous systems have failed also (Awayda and Subramanyam, 1998). This is not surprising if $\mathrm{DEG} / \mathrm{ENaC}$ channels require specialized extracellular and intracellular tethering proteins for mechanical gating (García-Añoveros and Corey, 1996, 1997), unlike mechanosensitive channels that may be opened by forces applied through the lipid bilayer (Morris, 1990; Sukharev et al., 1997). Therefore, functional testing of $\mathrm{BNaC} 1 \alpha$ channel mechanosensitivity most likely awaits the identification of these proteins and the reconstitution of a macromolecular touch-sensitive complex.

If $\mathrm{BNaC} 1 \alpha$ is a mechanotransducer, the diverse mechanosensitivity of $\mathrm{BNaC} 1 \alpha$-containing nerve terminals (low and high threshold, slowly and rapidly adapting) would imply that it contributes to different mechanosensory complexes. Channels with different properties might be obtained by forming heteromultimers with other subunits of the $\mathrm{BNaC}$ branch, like $\mathrm{ASIC} 1 \beta$ $(\mathrm{BNaC} 2 \beta)$, which also is expressed by subsets of $\mathrm{A}$ - and $\mathrm{C}$-fiber neurons (Chen et al., 1998), or with the subunits of the epithelial sodium channel $(\alpha, \beta$, and $\gamma$-ENaC), which recently have been detected in palisade nerve endings (Fricke et al., 2000). In addition, even homomultimeric channels might interact with different accessory proteins (such as extracellular tethering proteins) that convey tension with varying efficiencies. Finally, potential mechanosensory roles do not preclude activation by other physiological stimuli such as acidic $\mathrm{pH}$ or neuropeptides. In fact, most nociceptors are polymodal and respond to high-threshold mechanical stimuli, heat, or chemical stimuli, including acidic $\mathrm{pH}$. In nociceptor cells the $\mathrm{BNaCs}$ might form, alone or in combination with other proteins, ion channels that gate in response to a variety of stimuli. 


\section{REFERENCES}

Adams CM, Anderson MG, Motto DG, Price MP, Johnson WA, Welsh MJ (1998) Ripped pocket and pickpocket, novel Drosophila DEG/ $\mathrm{ENaC}$ subunits expressed in early development and in mechanosensory neurons. J Cell Biol 1:143-152.

Amaya F, Decosterd I, Samad TA, Plumpton C, Tate S, Mannion RJ, Costigan M, Woolf CJ (2000) Diversity of expression of the sensory neuron-specific TTX-resistant voltage-gated sodium ion channels SNS and SNS2. Mol Cell Neurosci 15:331-342.

Askwith CC, Cheng C, Ikuma M, Benson C, Price MP, Welsh MJ (2000) Neuropeptide FF and FMRFamide potentiate acid-evoked currents from sensory neurons and proton-gated $\mathrm{DEG} / \mathrm{ENaC}$ channels. Neuron 26:133-141.

Awayda MS, Subramanyam M (1998) Regulation of the epithelial $\mathrm{Na}^{+}$ channel by membrane tension. J Gen Physiol 112:97-111.

Babinski K, Lê K-T, Séguéla P (1999) Molecular cloning and regional distribution of a human proton receptor subunit with biphasic functional properties. J Neurochem 72:51-57.

Benson CJ, Eckert SP, McCleskey EW (1999) Acid-evoked currents in cardiac sensory neurons, a possible mediator of myocardial ischemic sensation. Circ Res 84:921-928.

Bevan S, Geppetti P (1994) Protons: small stimulants of capsaicinsensitive sensory nerves. Trends Neurosci 17:509-512.

Bevan S, Yeats J (1991) Protons activate a cation conductance in a subpopulation of rat dorsal root ganglion neurones. J Physiol (Lond) 433:145-161.

Bruce MF, Sinclair DC (1980) Relationship between tactile thresholds and histology of the human finger. J Neurol Neurosurg Psychiatry 43:235-242.

Canessa CM, Horrisberger JD, Rossier BC (1993) Epithelial sodium channel related to proteins involved in neurodegeneration. Nature 361:467-470.

Canessa CM, Schild L, Buell G, Thorens B, Gutschi I, Horrisberger JD, Rossier BC (1994) Amiloride-sensitive epithelial $\mathrm{Na}^{+}$channel is made of three homologous subunits. Nature 367:463-467.

Caterina MJ, Schumacher MA, Tominaga M, Rosen TA, Levine JD, Julius D (1997) The capsaicin receptor: a heat-activated ion channel in the pain pathway. Nature 389:816-824.

Caterina MJ, Leffler A, Malberg AB, Martin WJ, Trafton J, PetersenZeitz KR, Koltzenburg M, Basbaum AI, Julius D (2000) Impaired nociception and pain sensation in mice lacking the capsaicin receptor. Science 288:306-313.

Cauna N (1973) The free penicillate nerve endings of the human hairy skin. J Anat 115:277-288.

Cauna N, Ross LL (1960) Fine structure of Meissner's touch corpuscles of human fingers. J Biophys Biochem Cytol 8:467-482.

Chen C-C, England S, Akopian AN, Wood JN (1998) A sensory neuronspecific, proton-gated ion channel. Proc Natl Acad Sci USA 95:10240-10245.

Corey DP, García-Añoveros J (1996) Mechanosensation and the DEG/ ENaC ion channels. Science 273:323-324.

Darboux I, Lingueglia E, Pauron D, Barbry P, Lazdunski M (1998) A new member of the amiloride-sensitive sodium channel family in Drosophila melanogaster peripheral nervous system. Biochem Biophys Res Commun 246:210-216.

Driscoll M, Chalfie M (1991) The mec-4 gene is a member of a family of Caenorhabditis elegans genes that can mutate to induce neuronal degeneration. Nature 349:588-593.

Drummond HA, Price MP, Welsh MJ, Abboud FM (1998) A molecular component of the arterial baroreceptor mechanotransducer. Neuron 21:1435-1441.

Duggan A, García-Añoveros J, Corey DP (2000) Insect mechanoreception: what a long, strange TRP it's been. Curr Biol 10:R384-R387.

Fricke B, Lints R, Stewart G, Drummond H, Dodt G, Driscoll M, von Düring M (2000) Epithelial $\mathrm{Na}^{+}$channels and stomatin are expressed in rat trigeminal mechanosensory neurons. Cell Tissue Res 299:327-334.

García-Añoveros J, Corey DP (1996) Mechanosensation: touch at the molecular level. Curr Biol 6:541-543.

García-Añoveros J, Corey DP (1997) The molecules of mechanosensation. Annu Rev Neurosci 20:567-594.

García-Añoveros J, Ma C, Chalfie M (1995) Regulation of Caenorhabditis elegans degenerin proteins by a putative extracellular domain. Curr Biol 5:441-448.

García-Añoveros J, Derfler B, Neville-Golden J, Hyman BT, Corey DP (1997) $\mathrm{BNaC1}$ and $\mathrm{BNaC2}$ constitute a new family of human neuronal sodium channels related to degenerins and epithelial sodium channels. Proc Natl Acad Sci USA 94:1459-1464.

García-Añoveros J, García JA, Liu JD, Corey DP (1998) The nematode degenerin UNC-105 forms ion channels that are activated by degeneration- or hypercontraction-causing mutations. Neuron 20:1231-1241.

Goldstein ME, House SB, Gainer H (1991) NF-L and peripherin im- munoreactivities define distinct classes of rat sensory ganglion cells. J Neurosci Res 30:92-104.

Guo A, Vulchanova L, Wang J, Li X, Elde R (1999) Immunocytochemical localization of the vanilloid receptor 1 (VR1): relationship to neuropeptides, the P2X3 purinoceptor, and IB4 binding sites. Eur J Neurosci 11:946-958.

Huang M, Chalfie M (1994) Gene interactions affecting mechanosensory transduction in Caenorhabditis elegans. Nature 367:467-470.

Ishibashi K, Marumo F (1998) Molecular cloning of a DEG/ENaC sodium channel cDNA from human testis. Biochem Biophys Res Commun 245:589-593.

Kruger L, Perl ER, Sedivec MJ (1981) Fine structure of myelinated mechanical nociceptor endings in cat hairy skin. J Comp Neurol 198:137-154.

Lawson SN, Waddell PJ (1991) Soma neurofilament immunoreactivity is related to cell size and fibre conduction velocity in rat primary sensory neurons. J Physiol (Lond) 435:41-63.

Lawson SN, Harper AA, Harper EI, Garson JA, Anderton BH (1984) A monoclonal antibody against neurofilament protein specifically labels a subpopulation of rat sensory neurones. J Comp Neurol 228:263-272.

Liu J, Schrank B, Waterston R (1996) Interaction between a putative mechanosensory membrane channel and a collagen. Science 273:361-364.

McCarter GC, Reichling DB, Levine JD (1999) Mechanical transduction by rat dorsal root ganglion neurons in vitro. Neurosci Lett 273:179-182.

Millard CL, Woolf CJ (1988) Sensory innervation of the hairs of the rat hindlimb: a light microscopic analysis. J Comp Neurol 277:183-194.

Morris CE (1990) Mechanosensitive ion channels. J Membr Biol 113:93-107.

Price M, Snyder P, Welsh MJ (1996) Cloning and expression of a novel human brain $\mathrm{Na}^{+}$channel. J Biol Chem 271:7879-7882.

Price MP, Lewin GR, McIlwrath SL, Cheng C, Xie J, Heppenstall PA, Stucky CL, Mannsfeldt AG, Brennan TJ, Drummond HA, Qiao J, Benson CJ, Tarr DE, Hrstka RF, Yang B, Williamson RA, Welsh MJ (2000) The mammalian sodium channel BNC1 is required for normal touch sensation. Nature 407:1007-1011.

Reeh PW, Steen KH (1996) Tissue acidosis in nociception and pain. Prog Brain Res 113:143-151.

Rice FL, Kinnman E, Aldskogius H, Johansson O, Arvidsson J (1993) The innervation of the mystacial pad of the rat as revealed by PGP 9.5 immunofluorescence. J Comp Neurol 337:366-385.

Rice FL, Fundin BT, Arvidsson J, Aldskogius H, Johansson O (1997) Comprehensive immunofluorescence and lectin binding analysis of vibrissal follicle sinus complex innervation in the mystacial pad of the rat. J Comp Neurol 385:149-184.

Sann H, McCarthy PW, Jancsó G, Pierau F-K (1995) RT97: a marker for capsaicin-insensitive sensory endings in the rat skin. Cell Tissue Res 282:155-161.

Sinclair DC (1982) Mechanisms of cutaneous sensation. London: Oxford UP.

Steen KH, Reeh PW, Anton F, Handwerker HO (1992) Protons selectively induce lasting excitation and sensitization to mechanical stimulation of nociceptors in rat skin in vitro. J Neurosci 12:86-95.

Sukharev SI, Blount P, Martinac B, Kung C (1997) Mechanosensitive channels of Escherichia coli: the MscL gene, protein, and activities. Annu Rev Physiol 59:633-657.

Tavernarakis N, Shreffler W, Wang S, Driscoll M (1997) unc-8, a DEG/ $\mathrm{ENaC}$ family member, encodes a subunit of a candidate mechanically gated channel that modulates $C$. elegans locomotion. Neuron 18:107-119.

Thompson RJ, Doran JF, Jackson P, Dhillon AP, Rode J (1983) PGP 9.5-a new marker for vertebrate neurons and neuroendocrine cells. Brain Res 278:224-278

Tominaga M, Caterina MJ, Malberg AB, Rosen TA, Gilbert H, Skinner K, Raumann BE, Basbaum AI, Julius D (1998) The cloned capsaicin receptor integrates multiple pain-producing stimuli. Neuron 21:531-543.

Vulchanova L, Riedl MS, Shuster SJ, Stone LS, Hargreaves KM, Buell G, Surprenant A, North RA, Elde R (1998) P2X3 is expressed by DRG neurons that terminate in inner lamina II. Eur $J$ Neurosci 10:3470-3478

Waldmann R, Lazdunski M (1998) $\mathrm{H}^{+}$-gated cation channels: neuronal acid sensors in the $\mathrm{NaC} / \mathrm{DEG}$ family of ion channels. Curr Opin Neurobiol 8:418-424.

Waldmann R, Champigny G, Voilley N, Lauritzen I, Lazdunski M (1996) The mammalian degenerin MDEG, an amiloride-sensitive cation channel activated by mutations causing neurodegeneration in Caenorhabditis elegans. J Biol Chem 271:10433-10436.

Waldmann R, Bassilana F, de Weille J, Champigny G, Heurteaux C, Lazdunski M (1997) Molecular cloning of a non-inactivating protongated $\mathrm{Na}^{+}$channel specific for sensory neurons. J Biol Chem 272: 20975-20978. 